Poniżej podaję skrócone wersje dwóch cyrkularzy ISCHE XVIII. Znajdują się w nich podstawowe informacje o konferencji. Ponieważ głównym językiem ISCHE jest angielski, informacje te przekazuje w tym wlaśnie języku. W imieniu Komitetu Organizacyjnego zapraszam wszystkich polskich historyków wychowania do wzięcia udziału w tej unikalnej w skali światowej imprezie historyczno-edukacyjnej. Dotychczas (16 luty 1996) awizuja w niej udzial najwybitniejsze postacie światowej historii wychowania.

Madyslawa Szulakiewicz

ISCHE XVIII Kraków

August 6-9, 1996

\title{
Schooling in changing societies historical and comparative perspectives (c. 1750-1996)
}

In modern times, certainly since the rise of the modern nation state and perhaps even earlier, civil authorities, whether local, regional or national, became increasingly interested in organizing and controlling education from the early grades through the university. At the same time, many educators subscribed to educational theories and educational practices that disregarded all boundaries, regional, national, political, racial, ethnic and gender. As modern societies became increasingly competitive with each other as well as increasingly interdependent and moved toward the creation of the global society, education was increasingly conceived of as an instrument for achieving society's social, political and economic agenda. Consequently, officials in the political sector often assumed responsibility for organizing and reforming education - for introducing new forms of schooling, new school subjects, new curricula, new methods for teaching and specified methods for evaluating both students and their teachers.

The historian of education now has the opportunity and the responsibility to investigate the nature of the relationship between education and the many changes in the social, economic, political and legal structures, especially those changes that have occured since the time of the Enlightenment, c. 1750 . Consideration of this relationship suggests many questions: Has education been the means whereby the social, political, economic and legal structures have been changed? $\mathrm{Or}$, are the various forms of education known to the historian the results of social, political, economic and legal structures? What are the relationships among classical, modern and post-modern educational theories and educational philosophies? Is the history of educational theories and educational philosophies? Is the history of educational reform instructive? How have the aims and purposes of education, pedagogical methods, curriculum, organization and administration of education been affected by deliberate attempts at educational reform? How have they been affected by changes in the social, political, economic and legal structures of society?

The conference will include plenary sessions for invited speakers, parallel paper sessions and round table discussions. The main language of the conference is English, but papers in the other ISCHE languages - French, German and Spanish - are welcome.

\section{Plenary Lectures}

Leading historians of education from Europe, North America, Africa and Australia have confirmed their readiness to deliver lectures at the ISCHE XVIII. They will discuss key issues on Schooling in Changing Societies or even on the History of Education within an international scope. We have already received proposals from several invited speakers who are going to present very interesting topics, for example: 
Johannes H. Jordan (RSA): Schooling in Changing African Societies: Before and After Independence (ca 1950-1996)

Roy Lowe (UK): Formal Education and the Suppression of Social Mobility: a view of the linkages between schooling and social change

John Ramsland (AUS): Schooling Outback Children in Post-Colonial Australia 1901-1950

L. Glenn Smith (USA): Quantum Physics and the Act of Knowing: Implications of the Wh $L i$ Masters for Educational History.

\section{Seminar Gropus}

1. Historical perspectives on how the relationship between socio-economic change and education.

2. Historical perspectives on the educational consequences of political change.

3. The history of educational reform: Can educational change be legislated?

4. How educational theories and educational philosophies have been used to change education? aims and purposes of education, curriculum, pedagogical methods, organisation and administration of education.

5. Historiographical and methodological developments.

\section{The ISCHE XVIII Program (Preliminary)}

The conference will include plenary sessions for invited speakers, parallel paper sessions and round table discussions. The program of the Conference is not completed yet, however its outline is ready. We will proceed according to the following schedule:

\section{Augast 6, 1996: Tuesday}

$09,00-16,00$ - Registration in the Hall of the Main Building of Cracow Pedagogical University $10,00-13,00$ - Sessions of the ISCHE Standing Working Groups

13,00-15,00 - First Business Meeting of the ISCHE Executive Committee

$16,00-19,15$ - Opening Session

$16,00-16,30$ - Official Addresses

$16,30-17,15$ - Plenary Lecture

$17,15-18,00$ - Plenary Lecture

19,00-21,00 - Welcome Dinner for Conference Participants

\section{August 7, 1996: Wednesday}

$09,15-10,00$ - Plenary Lecture (s)

$10,00-10,15$ - Tea/Coffee Break

$10,15-12,30$ - Parallel Paper Sessions

$13,00-14,00$ - Lunch

$15,00-15,45$ - Plenary Lecture (s)

15,45-16,00 - Tea/Coffee Break

16,00-18,00 - Parallel Paper Sessions

19,00-20,00 - Reception hosted by the Mayor of Cracow. City Hall

20,15 - 22,15 - Dinner

August 8, 1996: Thursday

$09,15-10,00$ - Plenary Lecture (s)

10,00-10,15 - Tea/Coffee Break

10,15-12,30 - Parallel Paper Sessions 
$13,00-14,00$ - Lunch

$14,30-15,15$ - Plenary Lecture (s)

$15,15-15,30$ - Tea/Coffee Break

15,30-16,30 - Round Table Debates

$16,30-18,00$ - General Assembly of the ISCHE for all Conference Participants

$19,00-21,00$ - Dinner

August 9, 1996: Friday

$09,15-10,00$ - Plenary Lecture (s)

$10,00-10,15$ - Tea/Coffee Break

10,15-11,45 - Parallel Paper Sessions

11,45-12,00 - Tea/Coflee Break

12,00-13,00 - Closing Session Plenary Lecture (s). Last Words

$13,15-14,15$ - Lunch

14,30-15,30 - Second Business Meeting of the ISCHE Executive Committee

$16,00-17,30$ - Excurion to the Jagiellonian University Museum

\section{Registration}

The Local Committee of the ISCHE XVIII anticipates two kinds of registration: one for participants and another for accompanying persons. Registered participants can attend all conference activities and will receive a copy of the Proceedings. Registered accompanying persons may take part in the social and cultural activities and is entitled to stay in low budget rooms at the University Hotel „Krakowiak”. Children under the age of 15 , registered as accompanying persons, will not need to pay the registration fees.

\section{TAKE ADVANTAGE OF REDUCED FEES FOR EARLY REGISTRANTS!}

\section{Registration fees}

(I) Full participant:

Before May 31, 1996: \$220 US

(II) Accompanying person

Before July 31, 1996: $\$ 250$ US

\$ 50 US

S 70 US

After July 31, 1996: \$ 300 US

S 100 US

Payments should be made in Polish currency or in the United States Dollars (\$US), using Swift Bank Transfer to:

Bank Przemyslowo-Handlowy (BPH), IV O/M Kraków, PL

Account no: 323415-1010

WSP, ISCHE Conference

Remark: Please send a copy of the bank transfer to the conference office.

\section{Accommodation}

A wide range of housing is available in Krakow but we would recommend quite comfortable and inexpensive University Academic Hotel „Krakowiak”, that is situated within walking distance of the conference venue. It offers double rooms with private showers and toilets. The price per single room (bed and breakfast) is $\$ 25$ US and per double room (two beds and two breakfasts) $\$ 30$ US - both for one night. The whole Hotel (about 130 rooms) has been booked for the ISCHE XVIII 
in 6 - 10 August, 1996. Rooms are available on a first come first serve basis. If you are interested in, please complete Application form 2 and mail it to the Conference office. There is no accommodation deposit.

Accommodation is also available in Continental Hotel (formerly Holiday Inn), Wanda Hotel Orbis, Demel Hotel. They are all next to each other and are within very easy walking distance of the Cracow Pedagogical University where the conference will be held.

\section{Grants}

The local organisers hope that all historians of education and educators who wish to make a presentation can attend the ISCHE XVIII, including those who are from countries with limited resources. For this reason the Local Organising Committee is applying for financial support from different institutions to assist those who without this aid, would not be able to participate. Although there is no response from our prospective sponsors yet, we decided to encourange scholars who need financial support to apply for grants.

\section{ISCHE Committee}

Aurea ADAO (Portugal), James C. ALBISETI (USA), Richard ALDRICH - chair (England), Ning de CONINCK-SMITH (Denmark), Jeroen DEKKER - secretary (The Netherlands), Manfred HEINEMANN (Germany), Erwin V. JOHANNINGMEIER (USAL Antonio VINAO FRAGO (Spain).

\section{Local Committee}

Prof. dr Czesław Majorek - Chairman

Prol. dr Zygmunt Ruta - History of Education Chair

Dr Jan Krukowski - Dean, Faculty of Education

Dr Andrzej Kliś, Dr Wacław Marmon, Dr Jan Ryś, Dr Władysława Szulakiewicz,

Dr Wojciech Skołuba, Mgr Ryszard Ślęczka.

\section{Konferencje krajowe}

\section{Gdanisk - 20 maja 1996}

Zakład Historii Nauki, Oświaty i Wychowania Instytutu Pedagogiki Uniwersytetu Gdańskiego: ogólnopolska konferencja naukowa nt. „Historia - Edukacja” połączona z Jubileuszem Profesora dra hab. Lecha Mokrzeckiego.

W programie konferencji m.in.:

- postmodernistyczne problemy edukacji historycznej;

- badania nad oświatą i wychowaniem w XIX wieku w Królestwie Polskim;

- problemy edukacji galicyjskiej;

- polski mecenat naukowy w Rosji;

- historia wychowania w państwach niemieckich;

- zagadnienia współczesnej reformy oświaty w Polsce.

\section{Wrockaw - $11-12$ paździemik 1996}

Zakład Historii Oświaty i Wychowania Instytutu Pedagogiki Uniwersytetu Wrocławskiego: międzynarodowa konferencja naukowa nt. „Rola mniejszości narodowych w kulturze i oświacie polskiej od XVIII do XX w. (do 1939 r.)". 